\title{
PRENATAL TRACHEAL LIGATION OR INTRA- AMNIOTIC ADMINISTRATION OF SURFACTANT OR DEXAMETHASONE PREVENTS SOME STRUCTURAL CHANGES IN THE PULMONARY ARTERIES OF SURGICALLY CREATED DIAPHRAGMATIC HERNIA IN RABBITS
}

Consuelo J. Rodrigues, Uenis Tannuri, Ana Cristina A. Tannuri, João MaksoudFilho and Aldo J. Rodrigues Junior

RODRIGUES CJ et al. - Prenatal tracheal ligation or intra-amniotic administration of surfactant or dexamethasone prevents some structural changes in the pulmonary arteries of surgically created diaphragmatic hernia in rabbits. Rev. Hosp. Clín. Fac. Med. S. Paulo 57(1):1-8, 2002.

PURPOSE: Characterization of the structural changes occurring in the pulmonary arteries resulting from surgically produced congenital diaphragmatic hernia in rabbits, with particular emphasis on the preventive effects of prenatal tracheal ligation or administration of intra-amniotic dexamethasone or surfactant.

METHODS: Twenty rabbit fetuses underwent surgical creation of a left-sided congenital diaphragmatic hernia on the 24th or 25 th gestational day. They were divided according to the following procedures: congenital diaphragmatic hernia $(n=5)$, congenital diaphragmatic hernia plus tracheal ligation $(n=5)$, congenital diaphragmatic hernia plus intra-amniotic administration of dexamethasone $0.4 \mathrm{mg}(\mathrm{n}=5$ ) or surfactant (Curosurf $40 \mathrm{mg}, \mathrm{n}=5$ ). On gestational day 30, all the fetuses were delivered by caesarean section and killed. A control group consisted of five nonoperated fetuses. Histomorphometric analysis of medial thickness, cell nuclei density, and elastic fiber density of pulmonary arterial walls was performed.

RESULTS: Arteries with an external diameter $>100 \mu \mathrm{m}$ have a decreased medial thickness, lower cell nuclei density, and greater elastic fiber density when compared with arteries with external diameter $\leq 100 \mu \mathrm{m}$. Congenital diaphragmatic hernia promoted a significant decrease in medial thickness and an increase in cell nuclei density in artery walls with external diameter $>100 \mu \mathrm{m}$. Prenatal treatments with tracheal ligation or intra-amniotic administration of dexamethasone or surfactant prevented these changes. In arteries with external diameter $\leq 100 \mu \mathrm{m}$, congenital diaphragmatic hernia promoted a significant increase in medial thickness and in cell nuclei density and a decrease in elastic fiber density. The prenatal treatments with tracheal ligation or intra-amniotic administration of dexamethasone or surfactant prevented these changes, although no effect was observed in elastic fiber density in the congenital diaphragmatic hernia plus dexamethasone group.

CONCLUSIONS: Congenital diaphragmatic hernia promoted different structural changes for large or small arteries. The prenatal intra-amniotic administration of dexamethasone or surfactant had positive effects on the lung structural changes promoted by congenital diaphragmatic hernia, and these effects were comparable to the changes induced by tracheal ligation.

DESCRIPTORS: Congenital diaphragmatic hernia. Persistent pulmonary hypertension. Pulmonary hypoplasia. Surfactant. Glucocorticoid.

Patients with congenital diaphragmatic hernia $(\mathrm{CDH})$ have a high mortality rate, which has been attributed to pulmonary hypoplasia, pulmonary hypertension, and biochemical and structural immaturity of the lungs ${ }^{1-4}$. We have previously shown that fetal tra- cheal ligation (TL) reverses pulmonary hypoplasia in a rabbit model of $\mathrm{CDH}$

From the Laboratories of Surgical Anatomy (LIM-02) and Pediatric Surgery (LIM-30), Hospital das Clínicas, Faculty of Medicine, University of Sao Paulo. by accelerating fetal alveolar growth. In the same series of experiments, we also demonstrated that prenatal intraamniotic administration of surfactant or corticosteroids partially reverses the pulmonary hypoplasia of fetuses with $\mathrm{CDH}^{5}$. 
Clinical and animal studies have shown that lungs with $\mathrm{CDH}$ are less compliant than normal lungs ${ }^{6,7}$. This low compliance is attributable to a higher surface tension caused by surfactant deficiency and abnormal stiffness of lung parenchyma, which may be caused by an increased concentration of collagen and decreased density of elastic fibers ${ }^{5,8}$. Hedrick et al. ${ }^{9}$ demonstrated that prenatal glucocorticoid therapy improves pulmonary maturity parameters in rodent and sheep models of $\mathrm{CDH}$. Taira et al. ${ }^{10}$ reported that the administration of glucocorticoids has no effect on pulmonary tropoelastin and procollagen expression in lungs with $\mathrm{CDH}$. However, in a previous study of lung glycogen content, elastic fiber density, and collagen content, we verified that the effects of prenatal intra-amniotic administration of surfactant or dexamethasone are comparable to changes induced by TL; therefore, these drug therapies may be substitutes for $\mathrm{TL}^{8}$.

The pulmonary vascular abnormalities that have been implicated in pulmonary hypertension in $\mathrm{CDH}$ are a decrease in the number of pulmonary arteries per unit lung volume, an increase in the medial thickness, and primarily the muscularization of small arteries ${ }^{11}$. Furthermore, some authors have recently reported that in addition to the changes in the medial thickness of small pulmonary arteries, increased adventitial thickness is also a consistent feature. These structural changes may result from an increase in intramural pressure ${ }^{12-14}$.

The purpose of the current study was to investigate the structural changes in the pulmonary arteries of surgically created diaphragmatic hernia in rabbits and the preventive effects of prenatal TL or intraamniotic administration of dexamethasone or surfactant on these alterations.

\section{MATERIALS AND METHODS}

\section{Experimental Animals}

Twenty-five fetuses from 25 preg- nant New Zealand rabbits were distributed into 5 groups. For the experimental groups, 20 fetuses underwent surgical creation of a left-sided CDH on the 24 th or 25 th gestational day as previously described $^{5,8,15}$ (the normal full gestation time is 31 days). They were divided according to the following procedures: $\mathrm{CDH}(\mathrm{n}=5), \mathrm{CDH}$ plus TL $(\mathrm{n}=$ 5), $\mathrm{CDH}$ plus intra-amniotic administration of a single dose of dexamethasone $(0.4 \mathrm{mg}, \mathrm{n}=5)$ and $\mathrm{CDH}$ plus intra-amniotic administration of surfactant (40 mg of Curosurf, Pharmalab-Chiesi, São Paulo, Brazil, $n=5)$. After the surgical manipulations, each one received 400 $\mathrm{mg}$ of cephalothin intravenously and 5 mg of Depo-Provera ${ }^{\circledR}$ (NV, Upjohn, Belgium) intramuscularly.

On gestational day 30, all the fetuses were delivered by cesarean section and killed by intraperitoneal injection of thiobarbiturate. A control group consisted of 5 nonoperated fetuses.

\section{Tissue}

Lung tissue specimens were obtained from the central region of the lower lobe of the left lung of each animal. The lungs were previously perfused through the trachea with buffered formalin solution $(6 \%)$ at a pressure of $20 \mathrm{~cm}$ of $\mathrm{H}_{2} \mathrm{O}$ for 2 hours and immersed in the same formalin solution. The lung samples were embedded in historesin embedding medium (Leica) and sectioned at a setting of $1 \mu \mathrm{m}$ on a microtome (Leica RM 2035). The slides were stained for 10 minutes in a Meyer hematoxylin stain and for 1 hour in a resorcin-fuchsin (Weigert) stain for the nuclei and elastic fibers respectively.

\section{Morphometric Assessment of Pulmo- nary Arteries}

To determine whether the characteristic structural changes were size-related, arteries were grouped according to Brenner ${ }^{16}$ : (i) external diameter (ED)
$>100 \mu \mathrm{m}$ (the muscular arteries or preacinar arteries that accompany conducting airways); (ii) $\mathrm{ED} \leq 100 \mu \mathrm{m}$ (the arterioles or intra-acinar arterioles associated with the respiratory bronchi and saccules).

Morphometric measurements were performed with an optical electronic image analysis system (Kontron 300, UK). A blinded investigator then studied lung sections from 5 fetuses in each of the 5 groups. The transversely sectioned pulmonary arteries present in the tissue were examined to measure the following parameters: external diameter (ED), the diameter between the external elastic lamina; internal diameter (ID), the diameter between the internal elastic lamina; elastic fiber density in the arterial wall (EF), expressed as a fraction of the area; and cell nuclei density in the arterial wall (CD), expressed as cell nuclei/ $/ \mathrm{m}^{2}$. The medial wall thickness (MT) was calculated as half the difference between the mean ED and ID, divided by ED, according to Best and Heath ${ }^{17}$. Therefore, MT was expressed as a percentage of the external diameter of the vessel to nullify the effects of vasodilatation or vasoconstriction on the measurements, as previously discussed ${ }^{18}$. Large arteries were measured on the monitor from the microscope image with $\mathrm{x} 20$ or $\mathrm{x} 40$ objectives, and the smaller ones were measured with a x100 objective.

\section{Statistical Analysis}

The morphometric values were calculated from the groups and expressed as mean \pm standard desviation (SD), for each variable. All comparisons were performed using the analysis of variance (ANOVA) for parametric data or the ANOVA on Ranks and Dunn's method for multiple comparison procedure for non-parametric data. Analyses were performed with the SigmaStat 2.0 software package (Jandel Scientific). Significant results were obtained for $P<.05$. 


\section{RESULTS}

In all groups, pulmonary arteries with ED > $100 \mu \mathrm{m}$ exhibited an evident internal elastic laminae with some others exhibiting elastic laminae in the medial wall (Fig. 1). Arteries with ED $\leq 100 \mu \mathrm{m}$ exhibited evident internal elastic laminae and some elastic fibers in the medial wall that may or may not constitute an elastic lamina. The small ones showed some elastic fibers in their medial wall (Fig. 2). Between these elastic laminae or fibers, we could see the nuclei of the smooth muscle cells arranged in concentric layers (Fig. 3).

The data from the morphometric analyses of pulmonary arteries with ED $>100 \mu \mathrm{m}$ and $\mathrm{ED} \leq 100 \mu \mathrm{m}$ are expressed in tables 1 and 2 and in figs. 4 to 6.

In all groups, the comparisons of the parameters for arteries with ED > $100 \mu \mathrm{m}$ and arteries with $\mathrm{ED} \leq 100 \mu \mathrm{m}$ showed significant differences $(P<$ $.05)$. The muscular arteries (ED $>100$ $\mu \mathrm{m})$ revealed lower MT and lower $\mathrm{CD}$, but greater $\mathrm{EF}(P<.05)$.

The comparison of the parameters of the arteries with ED $>100 \mu \mathrm{m}$ between control and experimental groups showed that the $\mathrm{CDH}$ promoted a significant decrease $(P<.05)$ in MT. Considering the number of cell nuclei per square micrometer, we found that $\mathrm{CDH}$ promoted an increase in the cell density, in comparison to control animals. This change may be due to a decrease of the medial surface area of these arteries in the $\mathrm{CDH}$ lungs. The prenatal treatments with TL or intra-amniotic administration of dexamethasone or surfactant prevented these changes.

There was no difference between the control and experimental groups in $\mathrm{EF}$ in the walls of the pulmonary arteries with ED > $100 \mu \mathrm{m}$, although a nonsignificant decrease was observed in the $\mathrm{CDH}$ group.

The comparison between control and experimental groups showed that $\mathrm{CDH}$ promoted a significant increase $(P<.05)$ in MT of the arteries with ED $\leq 100 \mu \mathrm{m}$. We found that CDH promoted an increase in CD in comparison to that found in the control animals. This change may provide an explanation for the increased MT of these vessels. The prenatal treatments with TL or intra-amniotic administration of surfactant or dexamethasone prevented these changes.

$\mathrm{CDH}$ induced a decrease in $\mathrm{EF}$ in arteries with $\mathrm{ED} \leq 100 \mu \mathrm{m}$. There was no production of elastic fibers with the increased number of cells. The prenatal treatments with TL or administration of surfactant prevented this change, although no effect was observed in the $\mathrm{CDH}$ plus dexamethasone group.

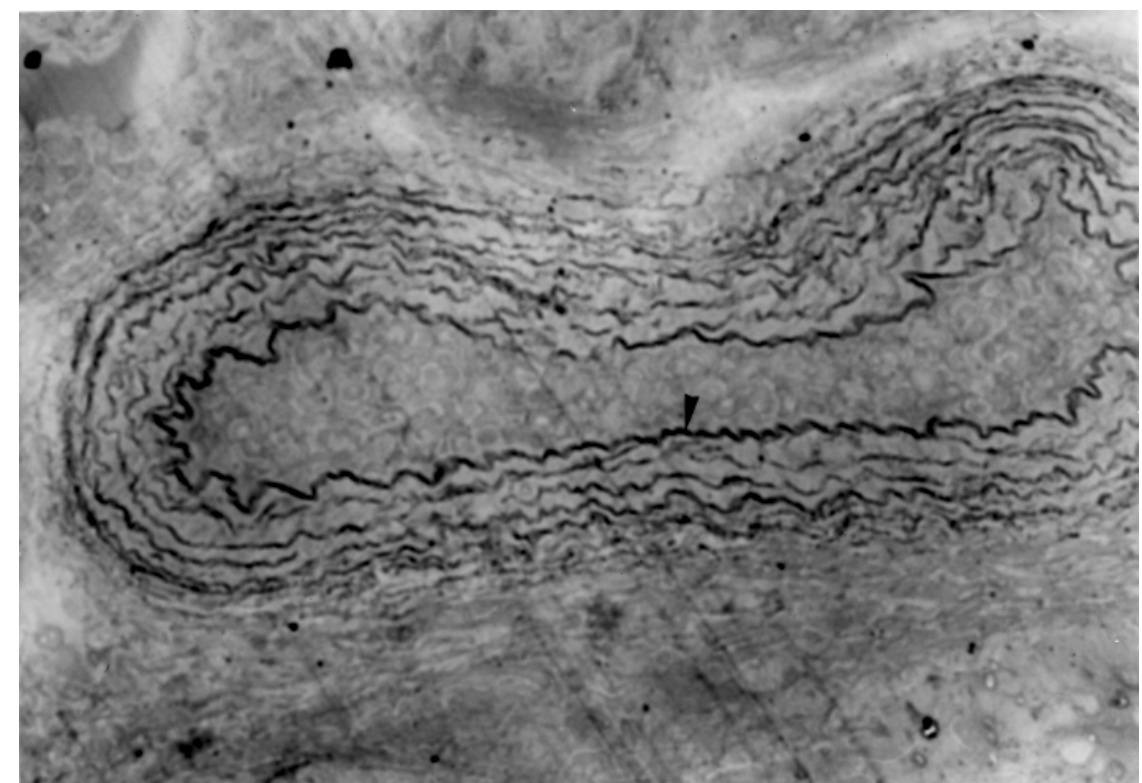

Figure 1 - Micrograph of a pulmonary artery with ED > $100 \mu \mathrm{m}$ showing an internal elastic laminae (arrowhead) with some other elastic laminae in the medial wall (Weigert-hematoxylin, $x 400$ ).

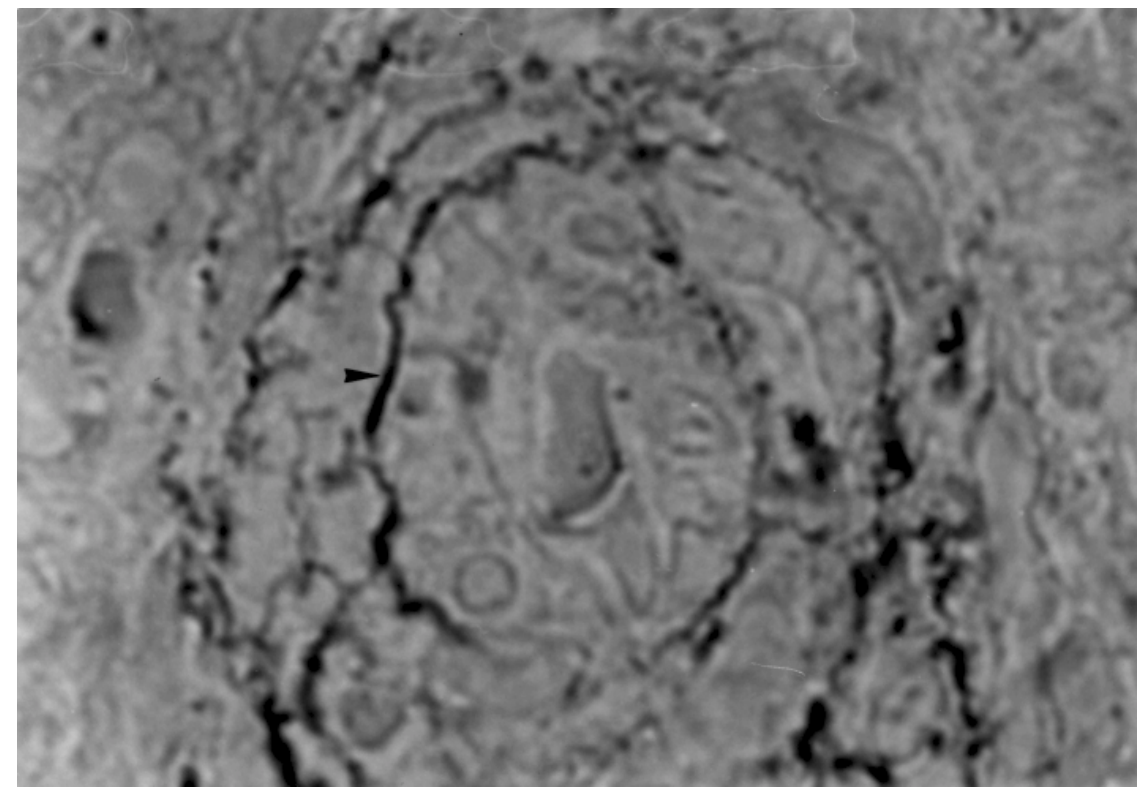

Figure 2 - Micrograph of a small pulmonary artery $(\mathrm{ED} \leq 100 \mu \mathrm{m})$ showing some elastic fibers (arrowhead) in the medial wall (Weigert-hematoxylin, x2000). 


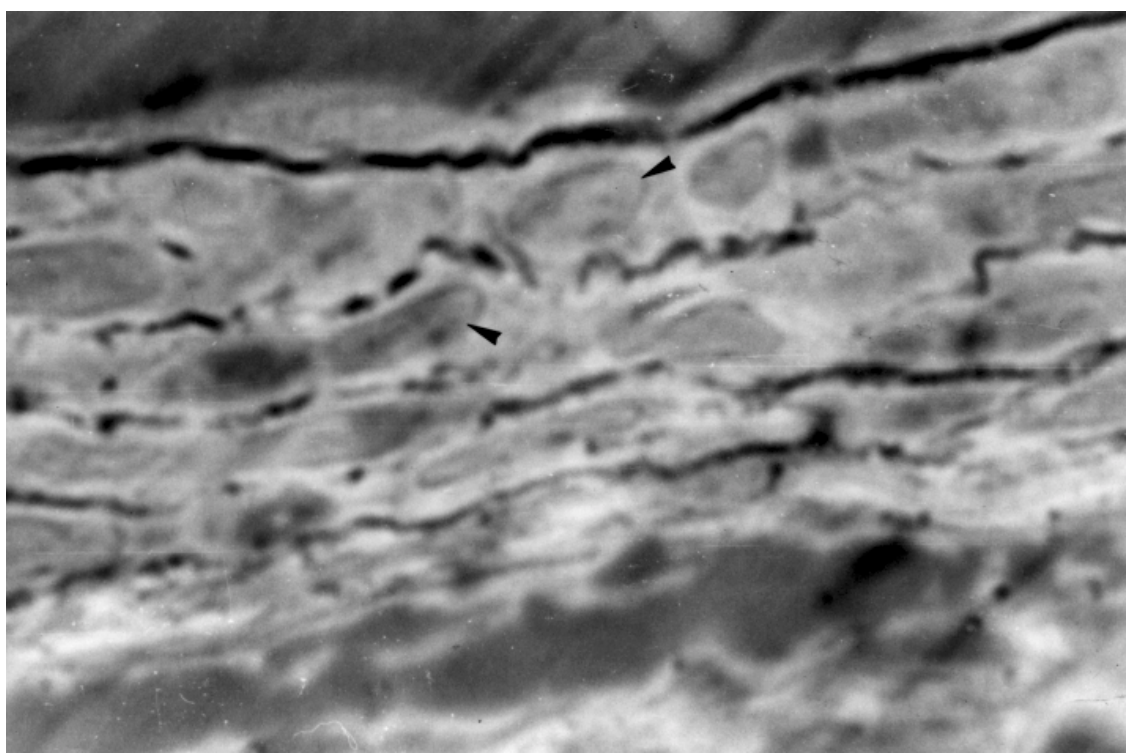

Figure 3 - Micrograph of medial wall of a pulmonary artery showing nuclei profiles (arrowheads) of the smooth muscle cells arranged in concentrical layers between the elastic laminae (Weigerthematoxylin, x2000).

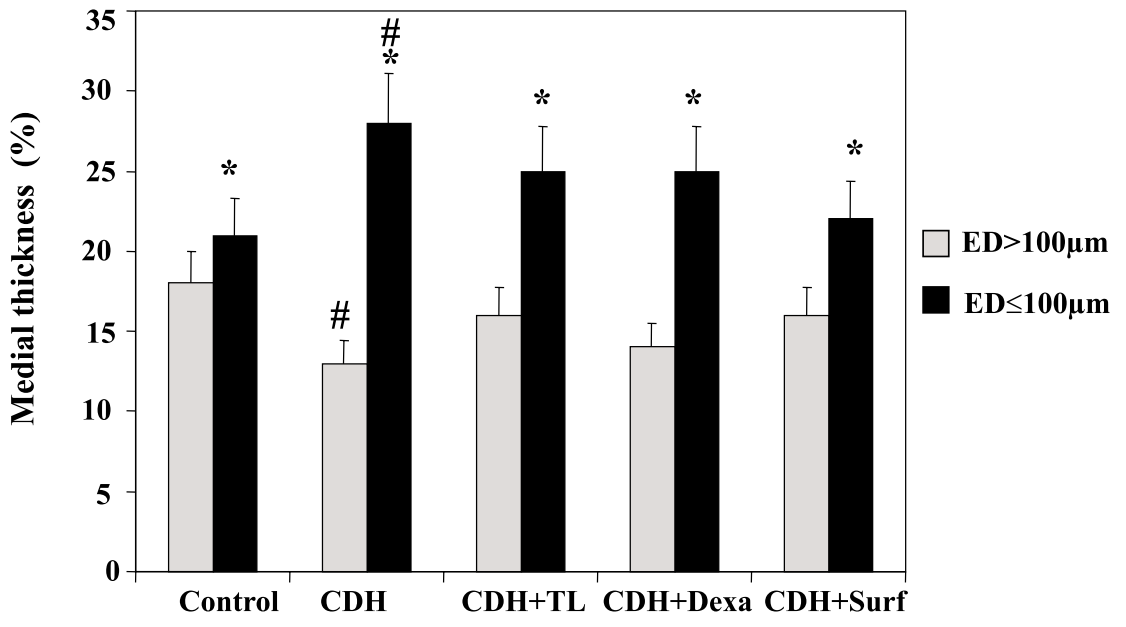

Figure 4 - Medial thickness (MT) of pulmonary arteries. (*) $P<.05$ - The comparisons between arteries with external diameter $(\mathrm{ED})>100 \mu \mathrm{m}$ and $\mathrm{ED} \leq 100 \mu \mathrm{m}$ demonstrate that the muscular arteries $(\mathrm{ED}>100 \mu \mathrm{m})$ have a decreased MT; (\#) $P<.05$ - relative to the control group. All the therapeutic procedures prevented the changes induced by congenital diaphragmatic hernia. The type of error bar (SD) should be noted.

\section{DISCUSSION}

Experimental model: We chose the rabbit model of $\mathrm{CDH}$ because it was previously standardized in our laboratory and shown to produce pulmonary hypoplasia ${ }^{8,15}$. In the current study, we aimed to study whether prenatal therapeutic procedures could prevent the structural changes in the pulmonary arteries induced by surgically created $\mathrm{CDH}$. To date, the only method that effectively treats or prevents all the changes of the herniated viscera on the developing lung in $\mathrm{CDH}$ fetus is tracheal occlusion, an invasive procedure. In 2 previous investigations, we proposed a new noninvasive therapeutic strategy, which consisted of prenatal intra-amniotic administration of high doses of swine surfactant $(40 \mathrm{mg}$ ) or dexamethasone $(0.4 \mathrm{mg})$, and we have proved that these treatments have positive effects on the immature lung of the fetal rabbit with $\mathrm{CDH}^{5,8}$, although we could not explain the mechanisms by which the intra-amniotic administered drugs produce their effects.

We chose the intra-amniotic route for administering the surfactant substance in the prenatal period to prevent pulmonary hypoplasia, since most investigations have used surfactant therapy prophylactically, i.e., before the onset of ventilation ${ }^{19}$. It has been suggested that when exogenous surfactant is considered for the newborn

Table 1 - Values of morphometric data of arteries with external diameter $>100 \mu \mathrm{m}$.

\begin{tabular}{lccccc}
\hline & Control & $\begin{array}{c}\text { Congenital } \\
\text { diaphragmatic } \\
\text { hernia }\end{array}$ & $\begin{array}{c}\text { Congenital } \\
\text { diaphragmatic hernia } \\
\text { + Tracheal ligation }\end{array}$ & $\begin{array}{c}\text { Congenital } \\
\text { diaphragmatic } \\
\text { hernia+Dexa }\end{array}$ & $\begin{array}{c}\text { Congenital } \\
\text { diaphragmatic } \\
\text { hernia+Surf }\end{array}$ \\
\hline External diameter(mean \pm SD) & $243.4 \pm 160.13$ & $181.5 \pm 65.41$ & $170.7 \pm 65.58$ & $213.4 \pm 78.22$ & $183.9 \pm 75.45$ \\
Internal diameter(mean \pm SD) & $155.3 \pm 98.46$ & $136.3 \pm 54.75$ & $117.1 \pm 47.15$ & $156.2 \pm 63.67$ & $127.7 \pm 58.59$ \\
\hline
\end{tabular}

Table 2 - Values of morphometric data of arteries with external diameter $\leq 100 \mu \mathrm{m}$.

\begin{tabular}{lcccc}
\hline & Control & $\begin{array}{c}\text { Congenital } \\
\text { diaphragmatic } \\
\text { hernia }\end{array}$ & $\begin{array}{c}\text { Congenital } \\
\text { diaphragmatic hernia } \\
\text { + Tracheal ligation }\end{array}$ & $\begin{array}{c}\text { Congenital } \\
\text { diaphragmatic } \\
\text { hernia+Dexa }\end{array}$ \\
\hline External diameter(mean \pm SD) & $64.6 \pm 18.93$ & $44.5 \pm 20.66$ & $52.7 \pm 19.61$ & $51.1 \pm 18.04$ \\
Internal diameter(mean \pm SD) & $37.6 \pm 11.76$ & $22.8 \pm 19.21$ & $27.7 \pm 16.88$ & $27.5 \pm 15.71$ \\
\hline
\end{tabular}




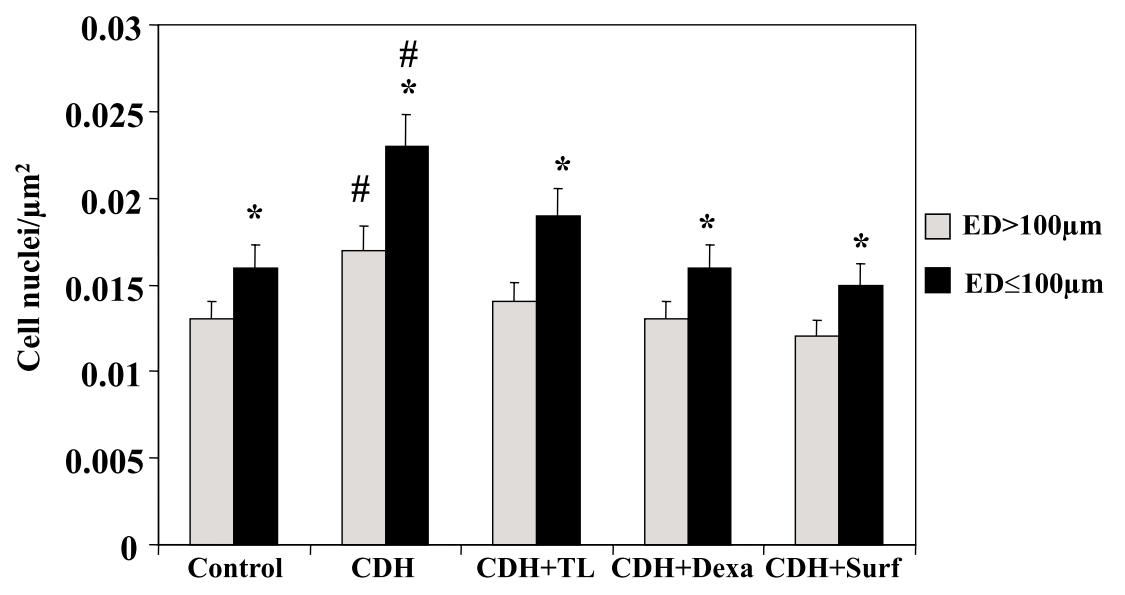

Figure 5 - Density of cell nuclei (CD) in the pulmonary arterial wall. $(*) P<.05$ - The comparisons between arteries with external diameter (ED) $>100 \mu \mathrm{m}$ and ED $\leq 100 \mu \mathrm{m}$ demonstrate that the muscular arteries (ED > $100 \mu \mathrm{m}$ ) have fewer cell nuclei per square micrometer; (\#) $P<.05$ - relative to the control group. All the therapeutic procedures prevented the changes induced by $\mathrm{CDH}$.

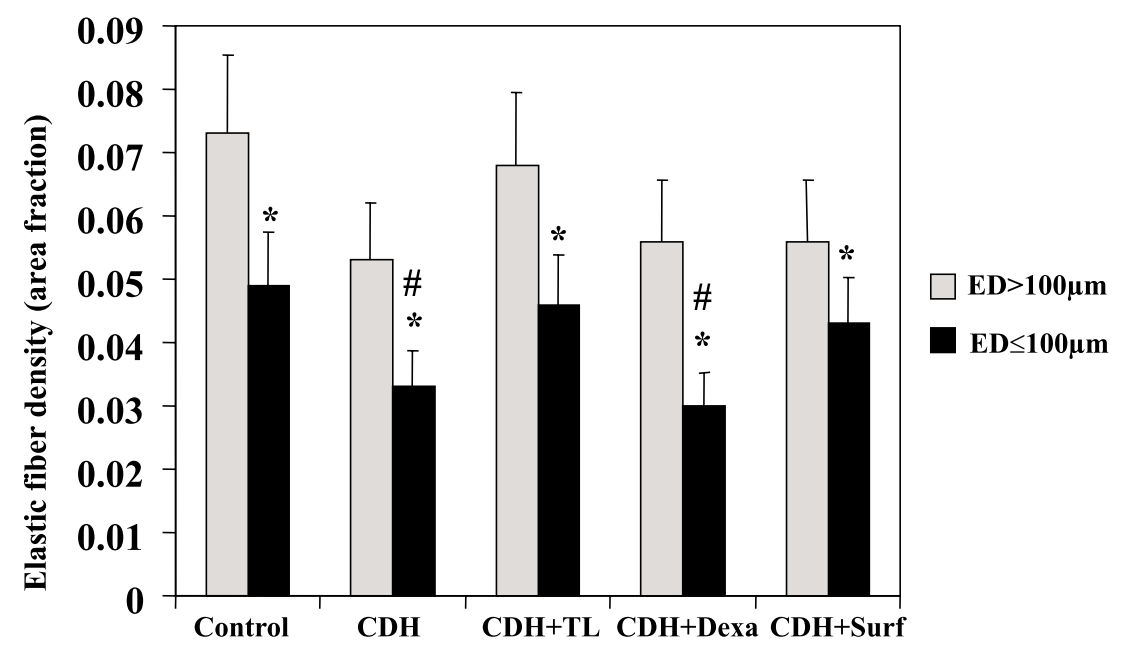

Figure 6 - Elastic fiber density (EF) (fraction of the pulmonary arterial wall area). (*) $P<.05-$ The comparison between arteries with external diameter (ED) $>100 \mu \mathrm{m}$ and $\mathrm{ED} \leq 100 \mu \mathrm{m}$; (\#) $P<.05-$ relative to the control group. There was no difference between the control and experimental groups in the arteries with ED $>100 \mu \mathrm{m}$. The therapeutic procedures, $\mathrm{TL}$, and prenatal intra-amniotic surfactant administration prevented the change induced by $\mathrm{CDH}$ in the arteries with $\mathrm{ED} \leq 100 \mu \mathrm{m}$.

with $\mathrm{CDH}$, it should be administered as early as possible, preferably before the infant's first breath ${ }^{20}$. Concerning the route of antenatal administration of glucocorticoids, we also chose the intra-amniotic one because we had previously noted that the intramuscular injection of dexamethasone into the pregnant does had a significant laborinducing effect, causing a high incidence of spontaneous abortion.

The respiratory movements of the fetus with inflow of the amniotic fluid begin early in pregnancy, and in addition to being a normal function of the fetus, play an important role in the development of the lungs ${ }^{21}$. Although many previous studies suggest that the fetal lungs produce a fluid that flows constantly from the lungs to the amniotic cavity ${ }^{22,23}$, there is some evidence that drugs infused into the amniotic cavity may be aspirated by the fetus. In experiments of transamniotic fetal feeding using a rabbit model and lipid emulsion as the nutrient, it was observed that the fetal alveoli were filled with lipid globules, which proved that amniotic fluid is chronically aspirated by the fetus ${ }^{24}$. In addition, in a previous similar investigation, we infused a mixture of porcine surfactant with microparticles of coal into the amniotic cavities of fetuses with $\mathrm{CDH}$ and of nonoperated littermates, and we noted that in all fetuses, the coal was massively aspirated into the lungs and trachea ${ }^{8}$.

It has been shown that $\mathrm{CDH}$ promotes alveolar hypoplasia, decreases the total size of the pulmonary vascular bed and the number of vessels per unit area of lung, and increases the muscularization of the arterial tree $e^{11,25-}$ ${ }^{27}$. Levin ${ }^{28}$ demonstrated that there is increased medial width and smooth muscle in resistance vessels in all lungs of patients with left-sided CDH and alveolar hypoplasia. Recently, Shehata et al. ${ }^{12}$ showed that raised levels of vascular endothelial growth factor occur in the medial smooth muscle cells of large and small pulmonary arteries in patients with $\mathrm{CDH}$.

In the present study, we demonstrated morphometric changes of the components of pulmonary arteries in rabbits with $\mathrm{CDH}$, and we verified a reversal of these changes with prenatal fetal treatments, utilizing TL or intra-amniotic administration of dexamethasone or surfactant. Emphasis was given here on the quantitative morphological differences between large and small arteries in control and experimental animals.

Morphometric measurements medial wall thickness (MT): In previous experiments, some authors reported that the hypoplasia of both large and capillary pulmonary vessels is related to a muscularization of pulmonary arterial vessels in animals with $\mathrm{CDH}$. They reported that fetal TL is capable of reversing these effects by accelerating both large vessel growth and capillary growth based on total large vessel area and total capillary number ${ }^{1,28}$. The TL treat- 
ment also appears to accelerate the lung maturation process ${ }^{19}$.

We also demonstrated that in the muscular pulmonary arteries with ED $>100 \mu \mathrm{m}, \mathrm{CDH}$ promoted a decreased MT, probably as a result of a vasodilatation phenomenon, similar to what occurs in patients with atrial septal defect and other congenital heart diseases characterized by the presence of high pulmonary blood flow over a prolonged period prior to the onset of pulmonary hypertension. A dilatation occurs in pulmonary vessels with a thinning of the media as an expression of the compensation to severe pulmonary resistance ${ }^{29}$.

Elastic fiber density and cell nuclei density in the pulmonary arterial wall: By definition, elastic arteries are those with one or more elastic laminae between internal and external elastic laminae, whereas the muscular arteries have only the internal and external elastic laminae ${ }^{16,30}$. In our study, the pulmonary arteries with ED $>100 \mu \mathrm{m}$ were characterized as muscular arteries and exhibited one or more additional elastic laminae between the internal and external elastic laminae. In contrast, the smaller arteries with ED $\leq 100 \mu \mathrm{m}$ had only a crescent of smooth muscle, and the internal elastic laminae disappeared, with some elastic fibers being observed between the muscle cells. This phenomenon may be caused by a reduced capacity for response to the physiological actions of contraction or dilatation, since we have demonstrated that these small vessels have a greater density of cell nuclei than do the muscular arteries with $\mathrm{ED}>100 \mu \mathrm{m}$. We suggest that the large arteries control the blood flow, while the small ones are responsible for the resistance of the flow.
The walls of the arteries with ED $\leq 100 \mu \mathrm{m}$ are thicker and have more cells per unit area than the muscular arteries with $\mathrm{ED}>100 \mu \mathrm{m}$, and this finding agrees with those of previous studies $^{1,25,28}$. The small arteries also have a lower tensile strength and thus can stretch farther to accommodate the higher interior pressure. The presence of abnormally thick-walled pulmonary arteries in stillborns with $\mathrm{CDH}$ suggests that the intrapulmonary arteries in $\mathrm{CDH}$ may become excessively muscularized during fetal life, becoming unable to adapt normally at birth ${ }^{31}$.

A previous investigation reported that some prenatal treatments improve these structural changes in the pulmonary arteries promoted by $\mathrm{CDH}$. Lipsett et al..$^{32}$ demonstrated that tracheal occlusion performed in the lamb model of CDH stimulates lung development and restores lung structure and maturity towards normal levels by gestational term. There was also an increased volume density of parenchyma, airspace, and gas-exchange surface. Okoye et al. ${ }^{11}$ studied the effect of prenatal glucocorticoids on pulmonary vascular muscularization in experimental CDH. They verified an increased MT ratio of preacinar and intra-acinar arteries in CDH and demonstrated that maternal administration of dexamethasone inhibits this medial hypertrophy. The same observation was made in rats with nitrofen-induced $\mathrm{CDH}^{33}$. However, Shehata et al. ${ }^{12}$ showed that treatment with extracorporeal membrane oxygenation (ECMO) did not improve this increase in arterial medial thickness in newborns with CDH. The ECMO-treated newborns with $\mathrm{CDH}$ showed a thinner arterial adventitia than did patients with $\mathrm{CDH}$ who did not receive this treatment.
We observed that there is an increase in cell density and a decrease in the density of elastic fibers in small pulmonary arteries of animals with $\mathrm{CDH}$. The prenatal treatments with TL or administration of surfactant or dexamethasone are capable of preventing the structural changes in arteries of all sizes, except that the administration of dexamethasone does not prevent any loss of elastic fibers in small pulmonary arteries. This last change may result in a less compliant arterial wall better suited to resisting the higher intra-arterial pressure. Yamataka and Puri reported similar results ${ }^{13,14}$, which showed an active synthesis of collagen in the media and adventitia of pulmonary arteries in patients with $\mathrm{CDH}$ complicated by persistent pulmonary hypertension.

In conclusion, the present study demonstrates that animals with $\mathrm{CDH}$ have different structural changes in large and small pulmonary arteries, confirming their diverse physiological function. Furthermore, this is the third study showing that prenatal intra-amniotic administration of dexamethasone or surfactant has positive effects on the lung structural changes promoted by $\mathrm{CDH}$, and that these effects are comparable to the changes induced by TL. Further studies in lambs must be undertaken to confirm these results before embarking in a clinical trial in humans.

\section{FINANCIAL SUPPORT}

Supported in part by grants from FAPESP 94/6056-5, 94/6055-9, 95/ 07397-3 and Braun Laboratories, São Paulo-SP, Brazil. 
RODRIGUES CJ e col. - Ligadura de traquéia no período pré-natal ou administração intra-amniótica de surfactante ou dexametasona evitam algumas alterações estruturais nas artérias pulmonares de fetos de coelho com hérnia diafragmática congênita produzida com cirurgia. Rev. Hosp. Clín. Fac. Med. S. Paulo 57(1):1-8, 2002.

OBJETIVO: Caracterização das alterações estruturais que ocorrem nas artérias pulmonares de fetos de coelho com hérnia diafragmática congênita produzida com cirurgia, com destaque especial aos efeitos preventivos da ligadura de traquéia ou administração intra-amniótica de dexametasona ou surfactante.

MÉTODOS: Vinte fetos de coelho foram submetidos a cirurgia para produção de hérnia diafragmática no $24^{\circ} \mathrm{ou}$ $25^{\circ}$ dia de gestação. Os animais foram divididos de acordo com os procedimentos: hérnia diafragmática congênita $(\mathrm{n}=5)$, hérnia diafragmática congê- nita com ligadura de traquéia $(\mathrm{n}=5)$, hérnia diafragmática congênita com administração intraamniótica de $0,4 \mathrm{mg}$ de dexametasona $(\mathrm{n}=5)$ ou surfactante ( $40 \mathrm{mg}$ de Curosurf, $\mathrm{n}=5$ ). No $30^{\circ}$ dia de gestação, todos os fetos foram retirados por cesariana e mortos. $\mathrm{O}$ grupo controle consistiu de 5 fetos normais não operados. Foram realizadas análises histomorfométricas da parede das artérias pulmonares: espessura da camada média, contagem do número de núcleos celulares e densidade de fibras elásticas.

RESULTADOS: As artérias com diâmetro externo > $100 \mu \mathrm{m}$ apresentaram diminuição da espessura da camada média, menor número de núcleos celulares por micrômetro quadrado e maior densidade de fibras elásticas em comparação com as artérias com diâmetro externo diâmetro externo $\leq 100$ $\mu \mathrm{m}$. A hérnia diafragmática congênita provocou significativa redução na espessura da camada média e aumento do número de núcleos nas artérias com diâmetro externo > $100 \mu \mathrm{m}$. Os méto- dos terapêuticos, ligadura de traquéia e administração intraamniótica de drogas promoveram reversão destas alterações. Nas artérias com diâmetro externo $\leq 100 \mu \mathrm{m}$ a hérnia diafragmática congênita provocou aumento da espessura da camada média e na contagem de núcleos e decréscimo da densidade de fibras elásticas. A ligadura de traquéia e a administração intraamniótica de surfactante ou dexametasona reverteram estas alterações embora esta última não tenha tido efeito sobre a densidade de fibras elásticas.

CONCLUSÃO: A hérnia diafragmática congênita provoca diferentes alterações estruturais nas pequenas e grandes artérias pulmonares. A administração intraamniótica de surfactante ou dexametasona tem efeitos positivos nestas alterações estruturais, comparáveis à ligadura de traquéia.

DESCRITORES: Hérnia diafragmática congênita. Hipertensão pulmonar persistente. Hipoplasia pulmonar. Surfactante. Glicocorticóide.

\section{REFERENCE}

1. KITIKAWA M, HISLOP A, BOYDEN E et al. - Lung hypoplasia in congenital diaphragmatic hernia. Br J Surg 1971;58:342-346

2. NGUYEN L, GUTTAM F \& DE-CHADEREVIAN JP et al. - The mortality in congenital diaphragmatic hernia. Is total pulmonary mass inadequate no matter what? Ann Surg 1983;198:766-770.

3. GEGGE RL, MURPHY JD, LANGLEBEN D et al. - Congenital diaphragmatic hernia: Arterial structure changes and persistent pulmonary hypertension after surgical repair. J Pediatr 1985;107:457-464.

4. SUEN HC, LOSTY P, DONAHOE PW et al. - Biochemical immaturity of lungs in congenital diaphragmatic hernia. J Pediatr Surg 1993;28:471-477.

5. TANNURI U, MAKSOUD FILHO JG, SANTOS MM et al. - The effects of prenatal intra-amniotic surfactant or dexamethasone administration on lung development are comparable to changes induced by tracheal ligation in an animal model of $\mathrm{CDH}$. J Pediatr Surg 1998;33:1198-1205.
6. LOTZE A, KNIGHT GR, ANDERSON KD et al. - Surfactant (Beractant) therapy for infants with congenital diaphragmatic hernia on ECMO: Evidence of persistent surfactant deficiency. J Pediatr Surg 1994;29:407-412.

7. WILCOX DT, GLICK PL, KARAMANOUKIAN HL et al. Pathophysiology of congenital diaphragmatic hernia IX: Correlation of surfactant maturation with fetal cortisol and triiodothyronine concentration. J Pediatr Surg 1994;29:825-827.

8. TANNURI U, RODRIGUES CJ, MAKSOUD FILHO JG et al. - The effects of prenatal intraamniotic surfactant or dexamethasone administration on lung development are comparable to changes induced by tracheal ligation in an animal model of $\mathrm{CDH}$ : Studies of lung glycogen content, elastic fiber density and collagen content. J Pediatr Surg 1998;33:1776-1783.

9. HEDRICK HL, KABAN JM, PACHECO BA et al. - Prenatal glucocorticoids improve pulmonary morphometrics in fetal sheep with CDH. J Pediatr Surg 1997;32:217-221. 
10. TAIRA Y, OUE T, SHIMA M et al. - Increased tropoelastin and procollagen expression in the lung of nitrofen-induced $\mathrm{DH}$ in rats. J Pediatr Surg 1999;34:715-719.

11. OKOYE BO, LOSTY PD, LLOYD DA et al. - Effect of prenatal glucocorticoids on pulmonary vascular muscularization in nitrofeninduced CDH. J Pediatric Surg 1998;33:76-80.

12. SHEHATA SMK, SHARMA HS, VAN DER STAAK FH et al. Remodeling of pulmonary arteries in human $\mathrm{CDH}$ with or without extracorporeal membrane oxygenation. J Pediatr Surg 2000; 35:208-215

13. YAMATAKA T \& PURI P - Pulmonary arterial structural changes in pulmonary hypertension complicating congenital diaphragmatic hernia. J Pediatr Surg 1997;32:387-390.

14. YAMATAKA T \& PURI P - Active collagen synthesis by pulmonary arteries in pulmonary hypertension complicated by $\mathrm{CDH}$. J Pediatr Surg 1997;32:682-687.

15. FAUZA DO, TANNURI U, AYOUB AAR et al. - Surgically produced congenital diaphragmatic hernia in fetal rabbits. J Pediatr Surg 1994;29:882-886.

16. BRENNER O - Pathology of vessels of pulmonary circulation. Arch Int Med 1935;56:211.

17. BEST PV \& HEATH D - Interpretation of the appearance of the small pulmonary blood vessels in animals. Circ Res 1961;9:288-294.

18. HOSODA Y - Pathology of pulmonary hypertension: a human and experimental study. Pathol Int 1994;44:241-267.

19. O'TOOLE SJ, KARAMANOUKIAN HL \& MORIN III FC - Surfactant decreases pulmonary vascular resistance and increases pulmonary blood flow in the fetal lamb model of congenital diaphragmatic hernia. J Pediatr Surg 1996;31:507-511.

20. O'TOOLE SJ, KARAMANOUKIAN HL, SHARMA A et al. Surfactant rescue in the fetal lamb model of congenital diaphragmatic hernia. J Pediatr Surg 1996;31:1105-1109.

21. POTTER EL \& BOHLENDER GP - Intrauterine respiration in relation to development of the fetal lung. Am J Obstet Gynecol 1941;42:1421.
22. SHERMETA DW \& OESCH I - Characteristics of fetal lung fluid production.. J Pediatr Surg 1986;16:943-946.

23. ALCORN D, ADAMSON T, LAMBERT T et al. - Morphologic effects of chronic tracheal ligation and drainage in the fetal lamb. J Anat 1976;122:649-660.

24. HARRISON MR \& VILLA RL - Trans-amniotic fetal feeding I Development of an animal model: Continuous amniotic infusion in rabbits. J Pediatr Surg 1982;17:376-380.

25. DIFIORI JW, FAUZA DO, SLAVIN R et al. - Experimental fetal tracheal ligation and congenital diaphragmatic hernia: a pulmonary vascular morphometric analysis. J Pediatr Surg 1995;30:917-924.

26. MURPHY JD, RAVINOVITCH M, GOLDSTEIN JD et al. - The structural basis of persistent pulmonary hypertension of the newborn infant. J Pediatr 1981; 98: 962-967.

27. GEGGEL RL \& REID LM - The structural basis of PPHN. Clin Perinatolm 1984;3:525-549.

28. LEVIN DL - Morphologic analysis of the pulmonary vascular bed in congenital left-sided diaphragmatic hernia. J Pediatr 1978;92:805809 .

29. HEATH D \& EDWARDS JE - The pathology of hypertensive pulmonary vascular disease. Circulation 1958;18:533-547.

30. HARRIS P \& HEATH D - The Human Pulmonary Circulation. In $3^{\text {rd }}$ ed. Edinburgh, Churchill, 1986. p 30-47.

31. TAIRA Y, YAMATAKA T, MIYAZAKI E et al. - Comparison of the pulmonary vasculature in newborns and stillborns with $\mathrm{CDH}$. Pediatr Surg Int 1998;14:30-35.

32. LIPSETT J, COOL JC, RUNCIMAN SI et al. - Effect of antenatal tracheal occlusion on lung development in the sheep model of $\mathrm{CDH}$ : morphometric analysis of pulmonary structure and maturity. Pediatr Pulmonol 1998;25:257-269.

33. TAIRA Y, MIYAZAKI E, OHSHIRO K et al. - Administration of antenatal glucocorticoids prevents pulmonary artery changes in nitrofen-induced CDH. J Pediatr Surg 1998;33:1052-1056.

Received for publication on March 19, 2001. 